\title{
The Influence of Viscosity on Cellular Natural Convection in a Horizontal Electrochemical Cell
}

\author{
M.E. Lago \\ Engineering Faculty, University of Los Andes, Mérida, Venezuela
}

A.A. Wragg

School of Engineering, University of Exeter, Exeter, U.K.

Received: June 30, 1994; November 14, 1994

Foi investigada experimentalmente a influência da viscosidade do eletrólito na conveç̧ão celular natural em processos de transferência de massa. A convecção celular foi produzida em uma célula eletroquímica horizontal estreita, com um cátodo inferior orientado para cima, e um ânodo superior oriertado para baixo, em um eletrólito acidificado de sulfato de cobre. Os padrões de convecção celular foram observados utilizando-se fotografias do eletrodepósito de $\mathrm{Cu}$ resultante no cátodo. Os transientes corrente-tempo foram registrados e refletiram os diferentes padrões convectivos observados. A viscosidade quase não teve efeito no número crítico de Rayleigh. Observou-se que o comprimento de onda das células de convecção aumentou um pouco com o aumento na viscosidade do eletrólito. Por outro lado, a viscosidade afetou o tempo crítico no qual foi possível detectar a convecção celular natural; quando a viscosidade foi aumentada observou-se um atraso no início da conveç̧ão. Os tempos para iniciação da convecção foram correlacionados com sucesso pela equação $\tau_{\mathrm{c}}=13,1 \mathrm{Ra}^{-0,59}$ para $2,7 \times 10^{3}<\mathrm{Ra}<1,9 \times 10^{6}$.

The influence of electrolyte viscosity on cellular natural convection in mass transfer was experimentally investigated. Cellular convection was produced in a horizontal narrow gap electrochemical cell with a lower up-facing copper cathode and an upper down-facing copper anode in an acidified cupric sulphate electrolyte. The cellular convective patterns were observed using photography of the resulting cathode electrodeposit of $\mathrm{Cu}$. Current-time transients were recorded and were found to reflect the different convective patterns observed. The viscosity had practically no effect on the critical Rayleigh number. The wavelength of the convection cells was found to increase slightly with an increase in electrolyte viscosity. However, the viscosity affected the critical time at which cellular natural convection was detectable; when the viscosity was increased a delay in the onset of convection was observed. Convection onset times were successfully correlated by the equation $\tau_{\mathrm{c}}=13.1 \mathrm{Ra}^{-0.59}$ for $2.7 \times 10^{3}<\mathrm{Ra}<1.9 \times 10^{6}$.

Keywords: natural convection, Bénard cells

\section{Introduction}

It is well known that when a horizontal fluid layer is heated from below a cellular flow structure occurs, the classical form being Bénard convection, characterized by hexagonally shaped cells. A similar situation may arise in mass transfer when a density reduction process takes place at a horizontal up-facing surface in a thin layer of fluid.

Cellular natural convection in mass transfer has certain characteristics. In recent work ${ }^{\prime}$, three different patterns of convective cells were observed in free convection by mass transfer. The shape and wavelength of these cells depended on the concentration and the depth of the fluid layer between the electrodes.

In heat transfer ${ }^{2,3,4}$ it was found that the critical Rayleigh number $\left(\mathrm{Ra}_{\mathrm{c}}\right)$ for a pure fluid is independent of the Prandtl number $(\mathrm{Pr}), \mathrm{Ra}_{\mathrm{c}}=1707.8$. Also, for convection in a horizontal porous layer $\mathrm{Ra}_{c}$ is independent of $\mathrm{Pr}$. However, other authors ${ }^{5}$ have theoretically shown that $\mathrm{Ra}_{\mathrm{c}}$ increases when Pr decreases. According to Lage et al. ${ }^{6}$, the discrepancy is due to extrapolations in the numerical calculation.

Cellular natural convection in mass transfer has not been as extensively investigated as that in heat transfer. 
In the present work the influence of the fluid viscosity on the characteristics and the onset of the cellular natural convection by mass transfer was studied. The purpose was to quantify the effects on the critical parameters.

\section{Experimental}

Cellular natural convection was observed using the electrochemical limiting diffusion technique. Experiments were carried out under natural convection conditions in which the fluid is stratified, an unstable inverse density gradient is produced and cellular natural convection takes place. Also, with the intention of comparing results when natural convection is absent, experiments were carried out in which only diffusive mass transfer took place in the presence of a stable density gradient.

\section{The experimental cell}

Cellular natural convection was produced in a cylindrical horizontal narrow gap electrochemical cell with a lower up-facing cathode and an upper down-facing anode. The cell was made of acrylic. The electrodes were circular copper plates and were of equal diameter $(2.88 \mathrm{~cm})$.

The gap between the electrodes $(\mathrm{h})$, was fixed with acrylic spacers of known thickness. Ten different spacers between $0.189 \mathrm{~mm}$ and $2.807 \mathrm{~mm}$ were used.

The electrochemical system was a solution of $0.1 \mathrm{M}$ $\mathrm{CuSO}_{4}$ with $1.5 \mathrm{M} \mathrm{H}_{2} \mathrm{SO}_{4}$ as the supporting electrolyte, to which glycerol $(1 \mathrm{M}$ to $3 \mathrm{M}$ ) was added to increase the viscosity. The viscosity values range covered from 1.2 to 3.7 centipoise. Experiments were carried out in each cell gap for every concentration.

The cell was thermostated at $25 \pm 0.1{ }^{\circ} \mathrm{C}$.

\section{Experimental procedure}

The copper electrodes used were polished with fine emery cloth, washed with distilled water, dried and placed in the cell. The cell was completely filled with the electrolyte, care being taken to eliminate residual bubbles.

The cell was set horizontally with the cathode at the bottom of the cell. The potential difference was fixed at the limiting current voltage. Then, the voltage was switched on and the current was continuously recorded.

After a few minutes that the current had reached its steady-state limiting value, the experiment was concluded. Each resulting cathode electrodeposit morphology was photographed and analyzed.

The purely diffusional experiments were carried out in the same manner as above, but with the cell inverted.

\section{Result and Discussion}

Figure 1 shows the experimental current-time curves obtained with an electrolyte of high viscosity ( $3 \mathrm{M}$ glycerol). The gap varies between $0.203 \mathrm{~mm}$ and $2.807 \mathrm{~mm}$. The current initially decreases rapidly during the diffusion transient and then increases rapidly with the onset of convection to produce oscillations which gradually decrease prior to the attainment of the steady state natural convection condition. This behavior is always observed when convective cells are formed.

The limiting current increases considerably with the convective motion, and when the separation between the electrodes decreases, but the onset of the cellular natural convection occurs earlier with a decrease in gap size.

With the inverted cell a typical diffusion transient curve is obtained (Fig. 1).

\section{Flow pattern formation}

It was found that the deposits produced by the cellular motion in solutions of increasing viscosity could be described as "labrynthine", "polygonal" and "diffuse polygonal", in a manner similar to that observed in solutions of lower viscosity ${ }^{1}$.

The "labrynthine" deposit pattern was formed with a very narrow gap $(0.189 \mathrm{~mm})$. When the gap increased, the rolls become more random. This cellular pattern may be regarded as a precursor of the three-dimensional "polygonal" patterns which are shown in Fig. 2. Figure 2a shows

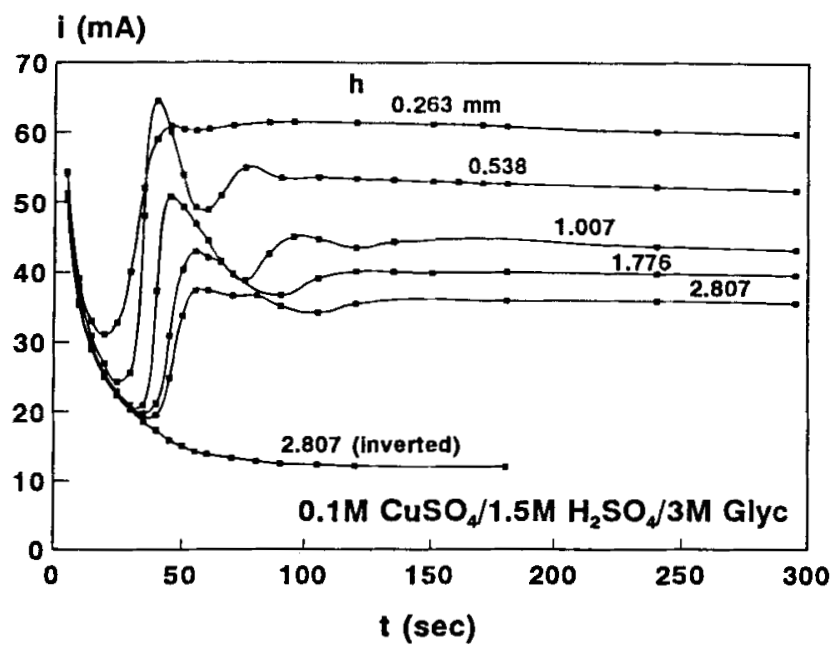

Figure 1. Current-time behavior for increasing gaps, with the system 0.1 $\mathrm{M} \mathrm{CuSO}_{4} / 1.5 \mathrm{M} \mathrm{II}_{2} \mathrm{SO}_{4} / 3 \mathrm{M}$ glycerol.
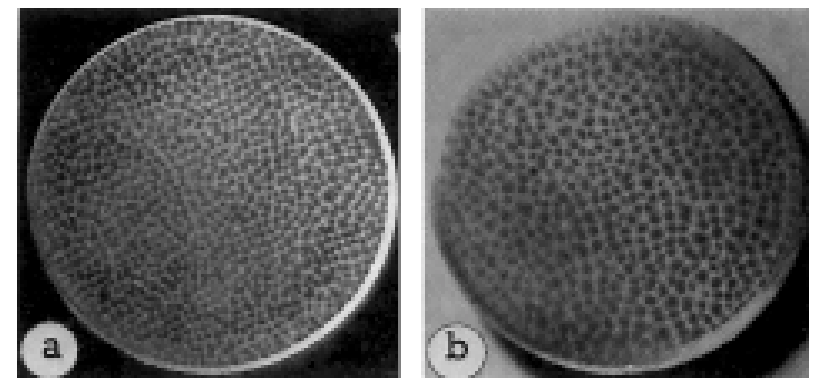

Figure 2. Effect of viscosity on the wavelength of the cellular patterns. a) c: $0.1 \mathrm{M} / 0 . \mathrm{M}$ glyc, $h=0.538 \mathrm{~mm}, \mu=1.212$ centipoise, b) c: $0.1 \mathrm{M} / 3$. $M$ glyc, $h=0.538 \mathrm{~mm}, \mu=3.611$ centipoise. 
the "polygonal" pattern obtained with a $0.1 \mathrm{M} \mathrm{CuSO}_{4} / 1.5$ $\mathrm{M} \mathrm{H}_{2} \mathrm{SO}_{4}$ solution without glycerol, and $2 \mathrm{~b}$ was obtained under the same conditions but with $3 \mathrm{M}$ glycerol. The viscosity increased from 1.212 centipoise (Fig. 2a) to 3.611 centipoise (Fig. 2b). However, the convective cells showed only a slight increase in wavelength $(\lambda)$.

The wave number is defined in linear stability theory as

$$
\alpha=\frac{2 \pi}{\lambda}
$$

where the wavelength $\lambda$ is the horizontal extension of the disturbance, measured in units of liquid depth ${ }^{7}$. Physically, this wavelength should appear as the period between rising streams or between down-flowing streams in the liquid layer ${ }^{8}$. In our system $\lambda$ is represented by the distance between the light lines in the photographs. The bright lines in Fig. 2 represent upflowing areas (the copper electrode practically free of deposit) and the dark areas represent downward flow (the accumulations of copper deposited as a dark circle in the center). Because the fluid density decreases at the surface of the cathode due to the electrolysis, the fluid become stratified. The denser liquid is at the top of each convective cell and down-flow results. Then, the less dense liquid at the bottom of each cell is displaced to the sides and upwards, initiating circulation. The measurements of $\lambda$ were made on enlarged photographs of the copper deposit of each experiment.

Figure 3 shows the relation between $\lambda$ and $\mu$ in the "polygonal" pattern of Fig. 2, obtained with $h=0.583 \mathrm{~mm}$. The "polygonal" pattern is formed by irregular polygonal cells. Because the patterns are not of a regular structure there is a range of $\lambda$ in each pattern. Figure 3 shows the maximum $\left(\lambda_{M}\right)$ and minimum $\left(\lambda_{m}\right)$ values of $\lambda$ for each value of $\mu$.

Similar results were obtained for the other flow patterns.

\section{Onset of instability}

The onset of instability was established as the time at which the first change in the current value from that in the diffusion experiments occurred. The time from the start of the electrolysis to the initiation of convection determines the critical time $\left(t_{c}\right)$.

In order to observe the influence of viscosity on the onset of instability several experiments were conducted under the same conditions in which only the viscosity was changed. The experimental results are shown in Fig. 4. From this figure a significant increase in the critical time with an increase in viscosity is observed.

The onset of cellular natural convection is clearly affected by the viscosity, as a delay is observed with viscosity increase.
Figure 5 shows the relation between $t_{c}$ and $h$ for electrolytes with increasing viscosity. The critical time increases significantly with an increase of viscosity, especially at lower gap values.

\section{Data evaluation}

Cellular natural convection is considered a problem of Rayleigh-Bénard instability for which a particularly relevant parameter is the Rayleigh number (Ra). Buoyancydriven convection is governed by the Rayleigh number, which is defined here as:

$$
\mathrm{Ra}=\frac{2 \mathrm{~g} \Delta \rho}{v \mathrm{D} \rho_{\mathrm{i}}} \mathrm{h}^{3}
$$

where $g=$ acceleration due to gravity, $v=$ kinematic viscosity, $\mathrm{D}=$ diffusion coefficient, $\Delta \rho=$ difference in density between the bulk solution and the electrode-solution interface, and $\rho_{i}=$ density at the electrode-solution interface. Because of the influence of the anodic diffusion layer at such close spacing the density difference is twice the dif-

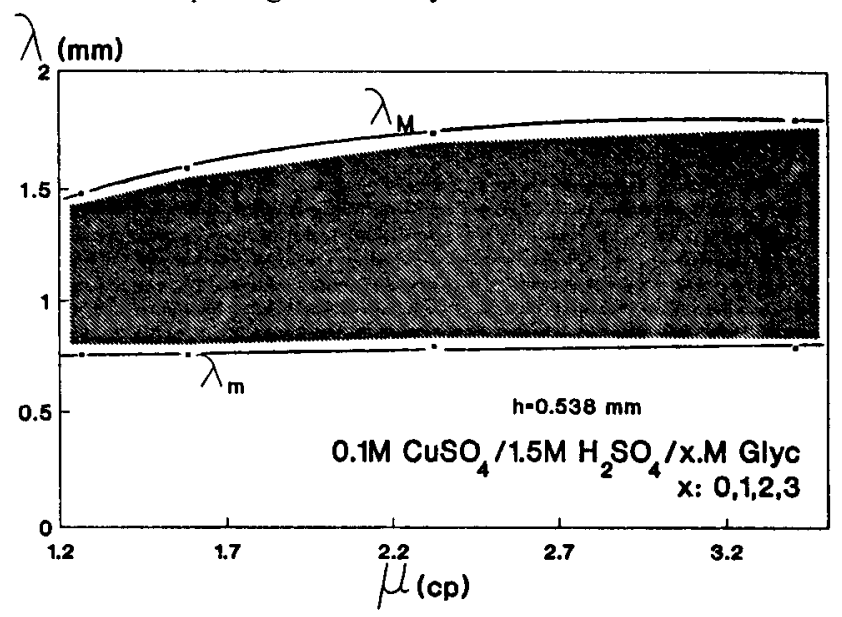

Figure 3. Wavelength of cellular patterns as a function of the electrolyte viscosily.

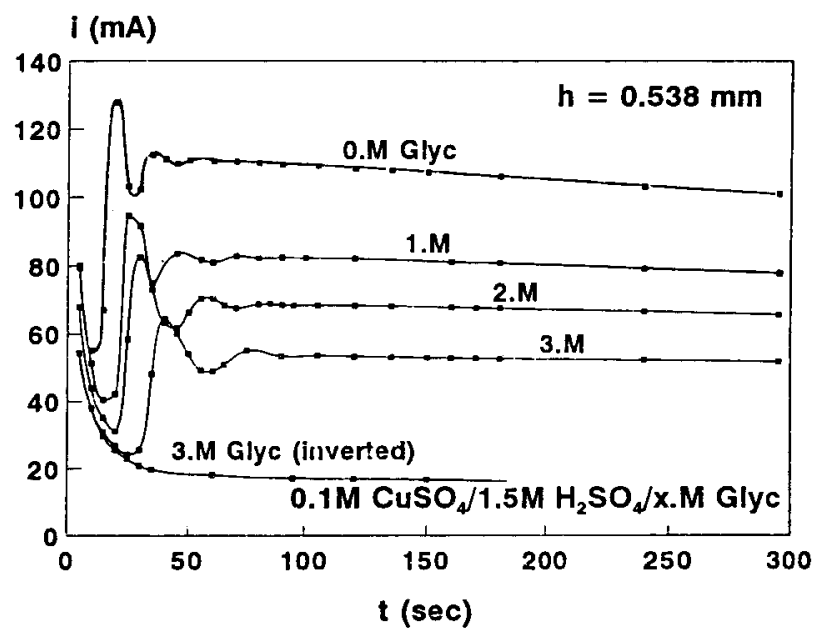

Figure 4. Current-lime behavior for electrolytes with increasing viscosity, with $\mathrm{h}=0.538 \mathrm{~mm}$. 


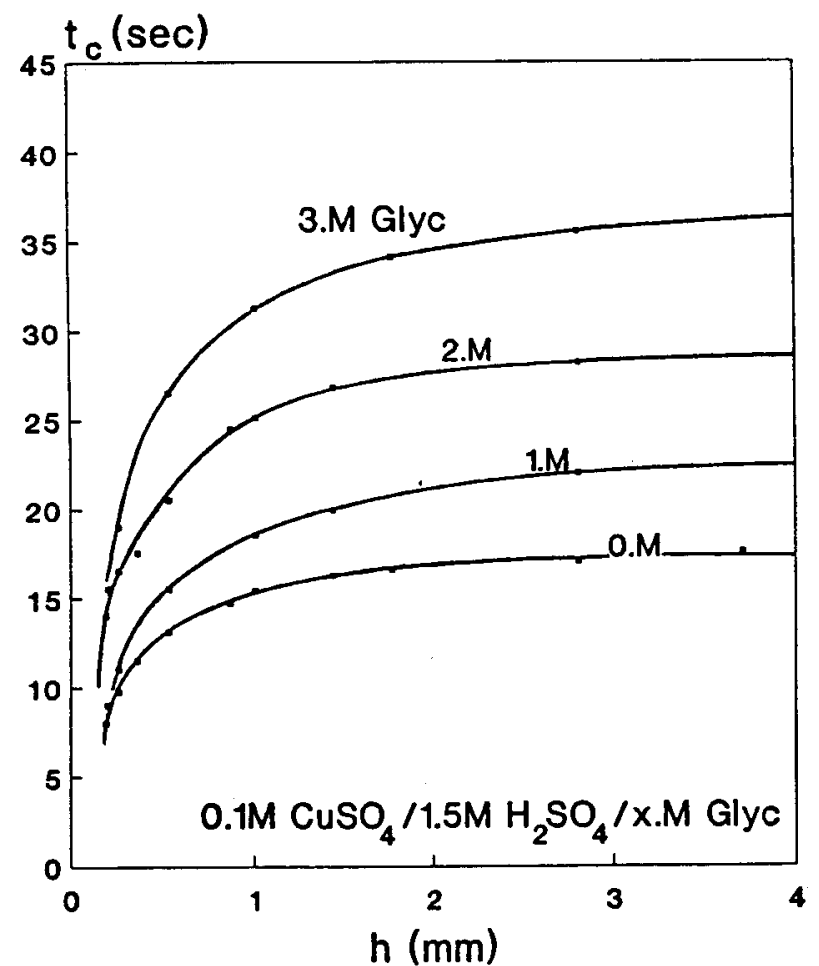

Figure 5. Critical time as a function of gap size for electrolytes with increasing viscosity.

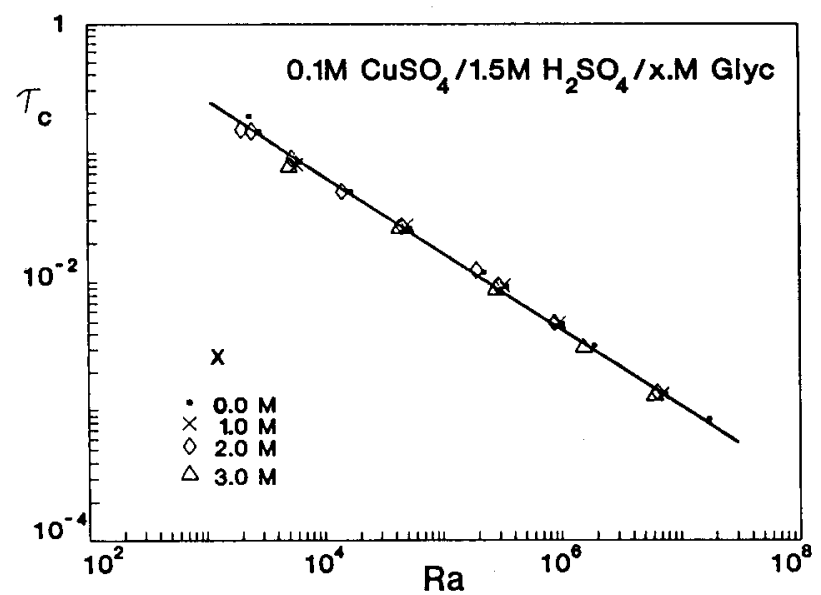

Figure 6. Correlation between eritical time $\tau_{\mathrm{c}}$ and the Rayleigh number $\mathrm{Ra}$.

ference in density between the bulk solution and the cathodic interface $(2 \Delta \rho)$.

Based on Rayleigh-Bénard convection the dimensionless critical time can be expressed as": $\tau_{c}=\frac{t_{c} D}{h^{2}}$

Beyond $\tau_{\mathrm{c}}$ cellular natural convection begins.

In Fig. 6, the experimental results for dimensionless critical time are plotted against $\mathrm{Ra}$. It can be seen that $\tau_{\mathrm{c}}$ decreases as $\mathrm{Ra}$ increases, and $\log \tau_{\mathrm{c}}$ appears to be a linear function of $\log \mathrm{Ra}$ over $\mathrm{Ra}=2.7 \times 10^{3}$. The relation between $\tau_{\mathrm{c}}$ and Ra may be expressed as:

$$
\tau_{\mathrm{c}}=13.1 \mathrm{Ra}^{-0.59} \text { for } 2.7 \times 10^{3}<\mathrm{Ra}<1.9 \times 10^{6}
$$

\section{Concluding Remarks}

An experimental investigation of cellular natural convection in mass transfer was performed using a horizontal narrow gap electrochemical cell with photography of the resulting cathode $\mathrm{Cu}$ electrodeposit to evaluate the influences of viscosity.

Experimental results show that an increase in the viscosity of the electrolyte produces a slight increase in the wavelength of the convective cells, but viscosity has little effect on the $R a_{c}$ of the system.

However, the viscosity of fluid affects the critical time for the onset of convection. An increase in the viscosity delays the onset of cellular natural convection.

The experimental values of the dimensionless critical time have been successfully correlated by the equation $\tau_{\mathrm{c}}=12.8 \mathrm{Ra}^{-0.57}$ for $2.7 \times 10^{3}<\mathrm{Ra}<1.9 \times 10^{6}$.

\section{References}

1. M.E. Lago and A.A. Wragg, Proceedings of the 44th Meeting of ISE (Berlin, 1993).

2. M.E.R. Proctor, J. Fluid Mech 137, 462 (1983).

3. J.L. Lage, A. Bejan and J.G. Georgiadis, Int. J. Heat Fluid Flow 12, 184 (1991).

4. J.G. Georgiadis, J. Heat Transfer 113, 1029 (1991).

5. N. Kladias and V. Prasad, J. Heat Transfer 111, 926 (1989).

6. J.L. Lage, A. Bejan and J.G. Georgiadis, Int. J. Heat and Fluid Flow 13, 4, 408 (1992).

7.E.L. Koschmieder, Adv. Chem. Phys. 26, 177 (1973).

8.E. Schmidt and P.L. Silveston, Chem. Eng. Progr. Symposium Ser. 29, 55, 163 (1959).

9. R.C. Nielsen and R.H. Sabersky, Int. J. Heat Mass Transfer 16, 2407 (1973). 